\title{
Role of CD152 genetic polymorphisms in the susceptibility to breast cancer
}

\author{
Hai Chen ${ }^{1}$, Xiaodong $\mathbf{Q i}^{1}$, Xue Bai ${ }^{1}$, Ping Qiu ${ }^{1}$, Bin Chen ${ }^{1}$ \\ ${ }^{1}$ Department of Galactophore, The General Hospital of Beijing Military Command, Beijing 100000, China \\ Correspondence to: Hai Chen, email: yuijicshygu@163.com \\ Keywords: CD152, CTLA-4, polymorphisms, breast cancer, immune response
}

Received: July 02, $2016 \quad$ Accepted: October 13, $2016 \quad$ Published: March 01, 2017

Copyright: Chen et al. This is an open-access article distributed under the terms of the Creative Commons Attribution License (CC-BY), which permits unrestricted use, distribution, and reproduction in any medium, provided the original author and source are credited.

\section{ABSTRACT}

Background: The polymorphisms in cluster of differentiation 152 (CD152) gene have been reported to be associated with breast cancer (BC), but relevant findings were far from conclusive. Therefore, we carried out this meta-analysis to combine those results for a clearer perspective on this issue.

Results: In our meta-analysis, a total of 8 eligible publications of 19 case-control studies were selected, which totally contained 7,442 BC cases and 7,376 normal controls. Among the five polymorphisms of CD152 gene, +49 G/A, $-1661 \mathrm{~A} / \mathrm{G}$ and $-318 \mathrm{C} / \mathrm{T}$ significantly increased the risk of $\mathrm{BC}$ under corresponding genetic comparisons; while CT60 G/A polymorphism was negatively related to the cancer susceptibility. In addition, -1772 T/C polymorphism of CD152 gene was not associated with the development of BC.

Materials and methods: Online databases and other sources were searched for published studies on the relationship between $B C$ susceptibility and CD152 polymorphisms (+49 G/A, -1661 A/G, -1722 T/C, $-318 \mathrm{C} / \mathrm{T}$ and CT60 G/A). The strength of association was evaluated with pooled odds ratios (ORs) and their corresponding $95 \%$ confidence intervals (95\% CIs). Heterogeneity evaluation was conducted via $Q$ test. Sensitivity analysis was used to detect the stability of our results. Begg's funnel plot and Egger's test were applied to investigate publication bias among selected studies.

Conclusions: The polymorphisms +49 G/A, -1661 A/G and $-318 \mathrm{C} / \mathrm{T}$ may elevate the susceptibility to $\mathrm{BC}$, but the polymorphism CT60 G/A may offer protection against the cancer.

\section{INTRODUCTION}

Breast cancer (BC) is the most commonly diagnosed malignancy and a leading cause of cancer-related deaths in women around the world [1,2]. The global incidence rate of $\mathrm{BC}$ is about $13 \%$, and shows an upward tendency in both developing and developed countries and regions $[3,4]$. The exact mechanism of breast cancer initiation is still beyond totally understood, though many factors have been identified to affect the pathogenesis of this malignancy. Studies have pointed out that the development of $\mathrm{BC}$ is affected by multiple epidemiological factors, such as age, female reproductive status, short period of or no breast feeding, use of oral contraceptive, and previous benign breast disease $[5,6]$. In addition, some environmental factors, such as chemical carcinogens and ionizing radiation, have also been proposed to contribute to increased risk of $\mathrm{BC}$ [7]. However, only a few of people exposed to these factors develop BC, indicating the important role of genetic factors $[8,9]$.

Cluster of differentiation 152 (CD152), also know as cytotoxic T-lymphocyte-associated protein 4 (CTLA-4), is a homologue of CD28, and functions as an inhibitor receptor for B7 which is a co-stimulatory molecule on mature antigen-presenting cells $[10,11]$. CD152 acts as a negative regulator of T cells involved in antitumor immune responses [12], and its blockade can promote immune responses [13] and reject tumors [14]. The hypothesis has been put forward that CD152 may attenuate the antitumor responses and increase cancer susceptibility via elevating the activation threshold of $\mathrm{T}$ cells in early stage of tumorigenesis [15]. Human CD152 gene is located on chromosome $2 \mathrm{q} 33$, and contains 4 exons 
coding for a leader sequence, an extracellular domain, a transmembrane domain and a cytoplasmic tail [16]. As a highly polymorphic gene, $C D 152$ has been identified to possess numerous polymorphisms, including $-1661 \mathrm{~A} / \mathrm{G}$, $-1722 \mathrm{~T} / \mathrm{C},-318 \mathrm{C} / \mathrm{T},+49 \mathrm{~A}>\mathrm{G}$ and CT60G/A [17]. These polymorphisms are functionally important, because they may affect immune responses via changing CD152 expression levels and functions on T cells. Specifically, they may alter the transcription capacity of the CD152 gene [18], the processing and transport of CD152 protein [19], and the interactions between CD152 and CD80 ligand [20]. Therefore, they have been widely explored their influences on autoimmune disorders [21] and cancer [22].

The polymorphisms $+49 \mathrm{G} / \mathrm{A}(\mathrm{rs} 231775),-1661 \mathrm{~A} / \mathrm{G}$ (rs4553808), -1722 T/C (rs733618), -318 C/T (rs5742909) and CT60 G/A (rs3087243) in the CD152 gene have been discussed their relationship with the susceptibility to BC in previous studies, but relevant findings were conflicting. So we performed this meta-analysis to pool these results for a more comprehensive conclusion.

\section{RESULTS}

\section{Study characteristics}

Altogether, 75 potentially relevant publications were initially retrieved using the searching strategy. After strict screening, 67 of them were excluded for not conforming to the criteria above mentioned (Figure 1), and finally, 8 eligible articles containing 19 case-control studies were incorporated into the present meta-analysis [23-30]. All of these studies were carried out in Asian populations, with population-based controls. Table 1 displays main information of each selected study.

\section{Meta-analysis results}

As described in Table 2, among five studied polymorphisms in CD152 gene, three of them were related to increased risk of $\mathrm{BC}$ and one was negatively associated with the cancer susceptibility, while the other one showed no significant relationship under any one of genetic contrasts. Specifically, the polymorphism +49 $\mathrm{G} / \mathrm{A}$ elevated the risk of $\mathrm{BC}$ under all five contrasts of AA vs. GG (Figure 2), AA+GA vs. GG, AA vs. GG + GA, A vs. G and GA vs. GG (Figure 3) (OR $=1.49,95 \%$ $\mathrm{CI}=1.24-1.79 ; \mathrm{OR}=1.27,95 \% \mathrm{CI}=1.14-1.40$; $\mathrm{OR}=1.25,95 \% \mathrm{CI}=1.08-1.46 ; \mathrm{OR}=1.19,95 \% \mathrm{CI}=$ $1.11-1.29 ; \mathrm{OR}=1.23,95 \% \mathrm{CI}=1.10-1.37)$; the -1661 $\mathrm{A} / \mathrm{G}$ polymorphism enhanced the $\mathrm{BC}$ susceptibility under $\mathrm{GG}+\mathrm{AG}$ vs. AA, $\mathrm{G}$ vs. A and $\mathrm{AG}$ vs. AA (Figure 3) genetic models; and the $-318 \mathrm{C} / \mathrm{T}$ polymorphism increased the $\mathrm{BC}$ risk under $\mathrm{CT}$ vs. CC comparison (Figure 3); while the polymorphism CT60 G/A expressed a reducing effect on BC susceptibility under AA vs. GG (Figure 2) and AA vs. GG+GA contrasts. As for the polymorphism $-1772 \mathrm{~T} / \mathrm{C}$, it showed no significant correlation with the susceptibility to BC.

\section{Heterogeneity test}

$Q$ test revealed no significant heterogeneity for the two polymorphisms of $+49 \mathrm{G} / \mathrm{A}$ and $-1661 \mathrm{~A} / \mathrm{G}$ under any genetic comparisons, so the fixed-effects model was chosen for ORs calculation. As for the other three

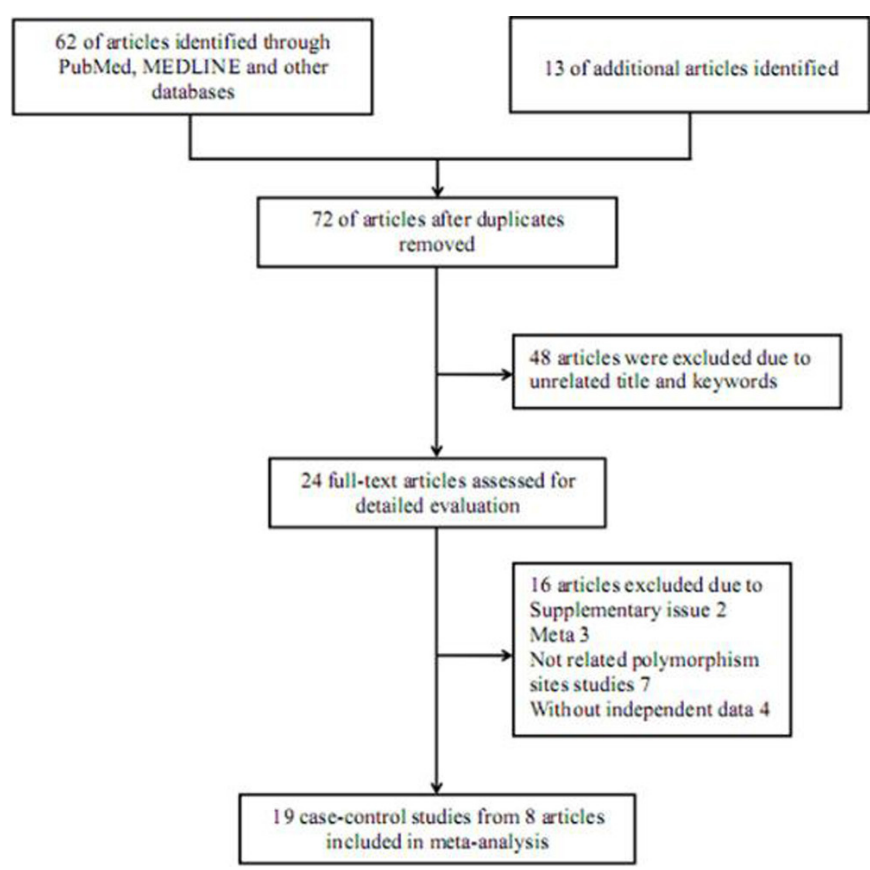

Figure 1: Flowchart of literature selection with detailed reasons for exclusion. 
Table 1: Main information of studies included in the meta-analysis

\begin{tabular}{|c|c|c|c|c|c|c|c|c|c|c|c|c|}
\hline \multirow{2}{*}{$\frac{\text { SNP }}{+49 \mathrm{G} / \mathrm{A}}$} & \multirow[t]{2}{*}{ First author } & \multirow[t]{2}{*}{ Year } & \multirow[t]{2}{*}{$\begin{array}{l}\text { Ethnicity } \\
\text { (Country) }\end{array}$} & \multirow[t]{2}{*}{$\begin{array}{c}\text { Genotyping } \\
\text { method }\end{array}$} & \multicolumn{3}{|c|}{ Case } & \multicolumn{3}{|c|}{ Control } & \multirow[t]{2}{*}{$\begin{array}{c}\text { Control } \\
\text { source }\end{array}$} & \multirow[t]{2}{*}{ HWE } \\
\hline & & & & & GG & GA & $\mathrm{AA}$ & GG & GA & AA & & \\
\hline & Ghaderi & 2004 & Asian (Iran) & PCR-RFLP & 9 & 104 & 84 & 19 & 72 & 60 & PB & 0.717 \\
\hline & Wang & 2007 & Asian (China) & PCR-RFLP & 10 & 59 & 48 & 23 & 70 & 55 & PB & 0.926 \\
\hline & Minhas & 2014 & Asian (India) & PCR-RFLP & 26 & 113 & 111 & 24 & 121 & 105 & PB & 0.197 \\
\hline & $\mathrm{Li}$ & 2012 & Asian (China) & PCR-RFLP & 246 & 281 & 49 & 256 & 243 & 54 & PB & 0.739 \\
\hline & Sun & 2008 & Asian (China) & PCR-RFLP & 474 & 485 & 101 & 559 & 446 & 65 & PB & 0.052 \\
\hline & Sun & 2008 & Asian (China) & PCR-RFLP & 482 & 455 & 100 & 546 & 451 & 73 & PB & 0.118 \\
\hline \multirow[t]{5}{*}{$-1661 \mathrm{~A} / \mathrm{G}$} & & & & & AA & $\mathrm{AG}$ & GG & AA & $\mathrm{AG}$ & GG & & \\
\hline & Wang & 2007 & Asian (China) & PCR-RFLP & 62 & 45 & 2 & 111 & 35 & 2 & PB & 0.683 \\
\hline & Kong & 2010 & Asian (China) & PCR-RFLP & 204 & 105 & 6 & 241 & 76 & 5 & PB & 0.721 \\
\hline & Erfani & 2006 & Asian (Iran) & PCR-RFLP & 211 & 65 & 6 & 184 & 43 & 11 & PB & 0.0003 \\
\hline & $\mathrm{Li}$ & 2012 & Asian (China) & PCR-RFLP & 405 & 153 & 16 & 425 & 115 & 11 & PB & 0.331 \\
\hline \multirow[t]{4}{*}{$-1722 \mathrm{~T} / \mathrm{C}$} & & & & & $\mathrm{TT}$ & $\mathrm{TC}$ & $\mathrm{CC}$ & $\mathrm{TT}$ & $\mathrm{TC}$ & $\mathrm{CC}$ & & \\
\hline & $\mathrm{Li}$ & 2008 & Asian (China) & PCR-RFLP & 125 & 163 & 40 & 111 & 168 & 48 & PB & 0.225 \\
\hline & $\mathrm{Li}$ & 2012 & Asian (China) & PCR-RFLP & 184 & 276 & 114 & 207 & 256 & 88 & PB & 0.552 \\
\hline & Erfani & 2006 & Asian (Iran) & PCR-CTPP & 225 & 54 & 3 & 204 & 41 & 0 & PB & 0.153 \\
\hline \multirow[t]{4}{*}{$-318 \mathrm{C} / \mathrm{T}$} & & & & & $\mathrm{CC}$ & $\mathrm{CT}$ & $\mathrm{TT}$ & $\mathrm{CC}$ & $\mathrm{CT}$ & $\mathrm{TT}$ & & \\
\hline & Wang & 2007 & Asian (China) & PCR-RFLP & 84 & 33 & 0 & 129 & 19 & 0 & PB & 0.404 \\
\hline & Kong & 2010 & Asian (China) & PCR-RFLP & 225 & 83 & 7 & 263 & 54 & 5 & PB & 0.257 \\
\hline & Erfani & 2006 & Asian (Iran) & PCR-ARMS & 244 & 38 & 1 & 206 & 31 & 4 & PB & 0.036 \\
\hline \multirow[t]{4}{*}{ CT60 G/A } & & & & & GG & GA & $\mathrm{AA}$ & GG & GA & $\mathrm{AA}$ & & \\
\hline & Wang & 2007 & Asian (China) & PCR-RFLP & 24 & 47 & 46 & 18 & 56 & 74 & PB & 0.155 \\
\hline & $\mathrm{Li}$ & 2008 & Asian (China) & PCR-RFLP & 32 & 124 & 172 & 20 & 114 & 193 & PB & 0.566 \\
\hline & $\mathrm{Li}$ & 2012 & Asian (China) & PCR-RFLP & 361 & 197 & 23 & 361 & 182 & 23 & PB & 0.992 \\
\hline
\end{tabular}

Notes: PCR-RFLP, polymerase chain reaction-restriction fragment length polymorphism; PCR-CTPP, polymerase chain reaction with confronting two pairs primers; PCR-ARMS, PCR-amplification refractory mutation system; HWE, HardyWeinberg equilibrium.

polymorphisms, the choice of which model being utilized was determined according to the standard above described.

\section{Sensitivity analysis}

Sensitivity analysis was performed for the polymorphisms $+49 \mathrm{G} / \mathrm{A}$ and $-1661 \mathrm{~A} / \mathrm{G}$, and no substantial alteration occurred during this process, indicating the final results were statistically robust. When it came to the other three polymorphisms, such analysis was not carried out for them due to limited number of included studies for each polymorphism.

\section{Publication bias investigation}

Begg's funnel plot and Egger's test were employed to inspect publication bias across included studies. As a result, the shape of funnel plots seemed symmetrical
(Figure 4), implying publication bias was negligible. Furthermore, these implications were all confirmed by statistical evidence from Egger's test $(P=0.447)$.

\section{DISCUSSION}

$\mathrm{BC}$ is the most frequent malignancy in women all over the world. The incidence rate of BC in China is lower than that in western countries, but it still shows a rising trend in the past few years, especially in those big coastal cities of this country. With complex pathogenesis, multiple factors may contribute to the occurrence and development of BC. Many elements have been identified as potential risk factors for $\mathrm{BC}$ onset, such as positive familial history of $\mathrm{BC}$, history of benign breast diseases, excessive exposure to ionizing radiation, early menarche, alcohol consumption, and excessive intake of saturated 
Table 2: $C D 152$ polymorphisms and breast cancer susceptibility

\begin{tabular}{|c|c|c|c|c|c|c|c|c|c|c|c|c|}
\hline \multirow{3}{*}{$\begin{array}{l}\text { Comparison } \\
22 \text { versus } 11\end{array}$} & \multicolumn{12}{|c|}{ Odds ratio ( $95 \%$ confidence interval) $/ P$ value for heterogeneity } \\
\hline & \multicolumn{2}{|c|}{$+49 \mathrm{G} / \mathrm{A}$} & \multicolumn{2}{|c|}{$-1661 \mathrm{~A} / \mathrm{G}$} & \multicolumn{2}{|c|}{$-1722 \mathrm{~T} / \mathrm{C}$} & \multicolumn{2}{|c|}{$-318 \mathrm{C} / \mathrm{T}$} & \multicolumn{2}{|c|}{ CT60 G/A } & \multicolumn{2}{|l|}{ Total } \\
\hline & $1.49(1.24,1.79)$ & 0.058 & $1.09(0.65,1.83)$ & 0.295 & $1.15(0.60,2.22)$ & 0.046 & $0.94(0.36,2.43)$ & 0.104 & $0.66(0.46,0.95)$ & 0.213 & $1.14(0.89,1.45)$ & 0.001 \\
\hline $22+12$ versus 11 & $1.27(1.14,1.40)$ & 0.148 & $1.48(1.24,1.77)$ & 0.218 & $1.12(0.93,1.33)$ & 0.100 & $1.61(0.94,2.78)$ & 0.026 & $0.76(0.46,1.23)$ & 0.047 & $1.26(1.10,1.43)$ & 0.000 \\
\hline 22 versus $11+12$ & $1.25(1.08,1.46)$ & 0.185 & $0.99(0.59,1.66)$ & 0.337 & $1.14(0.89,1.47)$ & 0.121 & $0.86(0.33,2.23)$ & 0.126 & $0.77(0.60,0.97)$ & 0.583 & $1.06(0.90,1.25)$ & 0.025 \\
\hline 2 versus 1 & $1.19(1.11,1.29)$ & 0.424 & $1.36(1.16,1.59)$ & 0.154 & $1.09(0.85,1.41)$ & 0.044 & $1.48(0.87,2.51)$ & 0.017 & $0.83(0.63,1.09)$ & 0.038 & $1.15(1.04,1.28)$ & 0.000 \\
\hline 12 versus 11 & $1.23(1.10,1.37)$ & 0.169 & $1.53(1.27,1.83)$ & 0.362 & $1.09(0.90,1.31)$ & 0.259 & $1.65(1.25,2.17)$ & 0.059 & $0.97(0.78,1.21)$ & 0.182 & $1.27(1.12,1.43)$ & 0.003 \\
\hline
\end{tabular}

Notes: 11 , wild homozygote; 12 , heterozygote; 22 , rare homozygote; 1 , wild allele; 2 , rare allele.

fatty acid and meat. However, among people exposing to the same environment and having similar lifestyle, only a part of them develop to BC. Although the initiation and progression of the majority of human cancers have been shown to be the results of combined actions between environmental and genetic factors, some studies demonstrate that heredity contributes to about one fourth of all $\mathrm{BC}$ cases. All these phenomenons imply that genetic factors play a critical role in the initiation of $\mathrm{BC}$.

As one of the most fundamental immunosuppressive cytokines, CD152 is mainly expressed on activated T cells. It functions as a restraining regulator for the proliferation and activation of $\mathrm{T}$ cells, further inhibiting the immune functions of $\mathrm{T}$ cells through inducing Fas-independent apoptosis of activated T cells. Additionally, CD152 is also expressed on different cellular types, both normal and neoplastic. CD152 can suppress cell-cycle progression through inhibiting interleukin-2 production, thus resulting in the induction and maintenance of $\mathrm{T}$ cell tolerance. The CD152 molecule can reduce the responses of $\mathrm{T}$ cells to foreign antigens and autoantigens under physiological conditions. It is up-regulated on the surface of the latter in tumor microenvironment. Besides, CD152 deficiency can lead to lethal diseases, including cancer. CD152

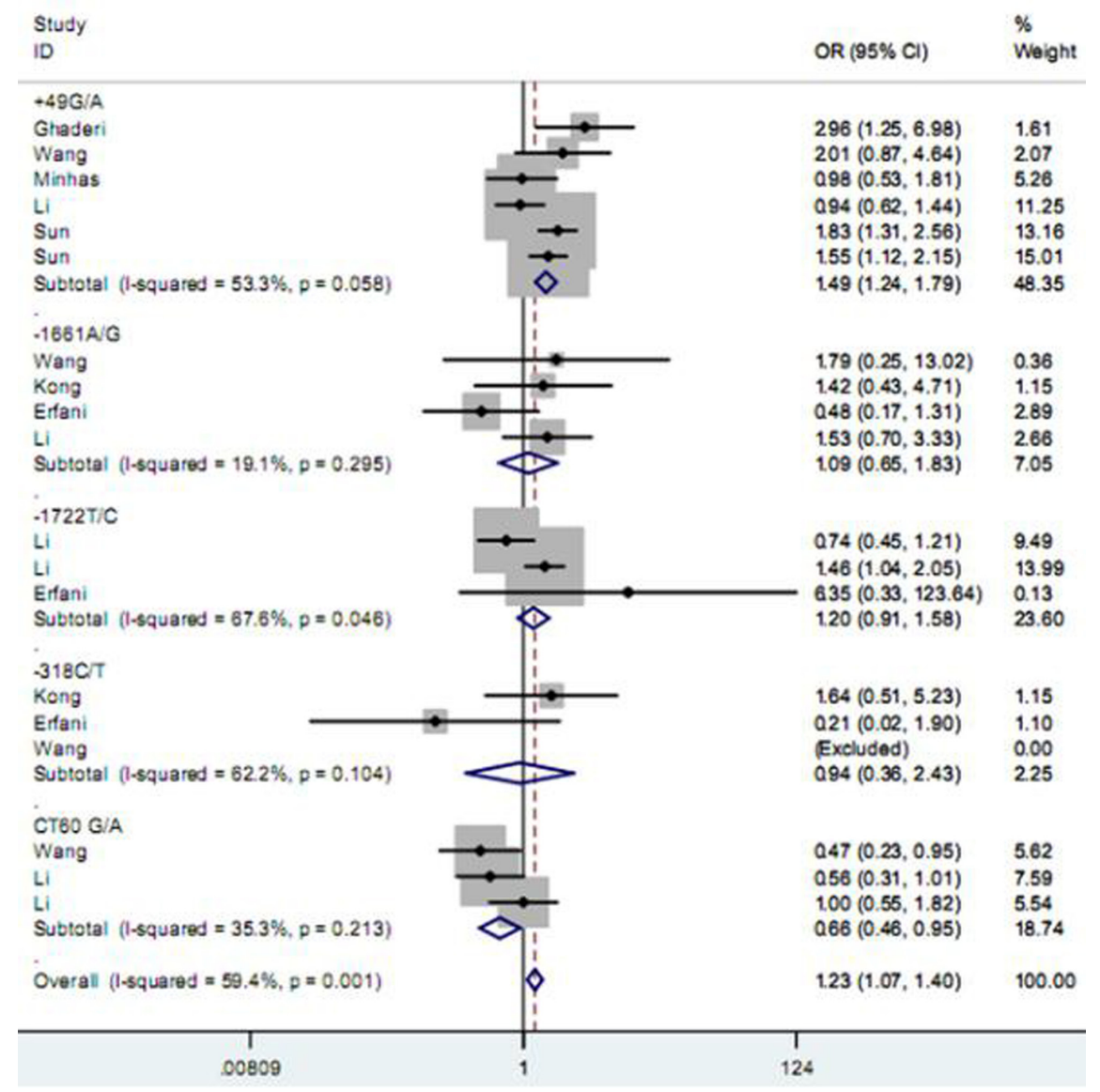

Figure 2: Forest plot for the association between CD152 polymorphisms and breast cancer susceptibility under homozygote model. 


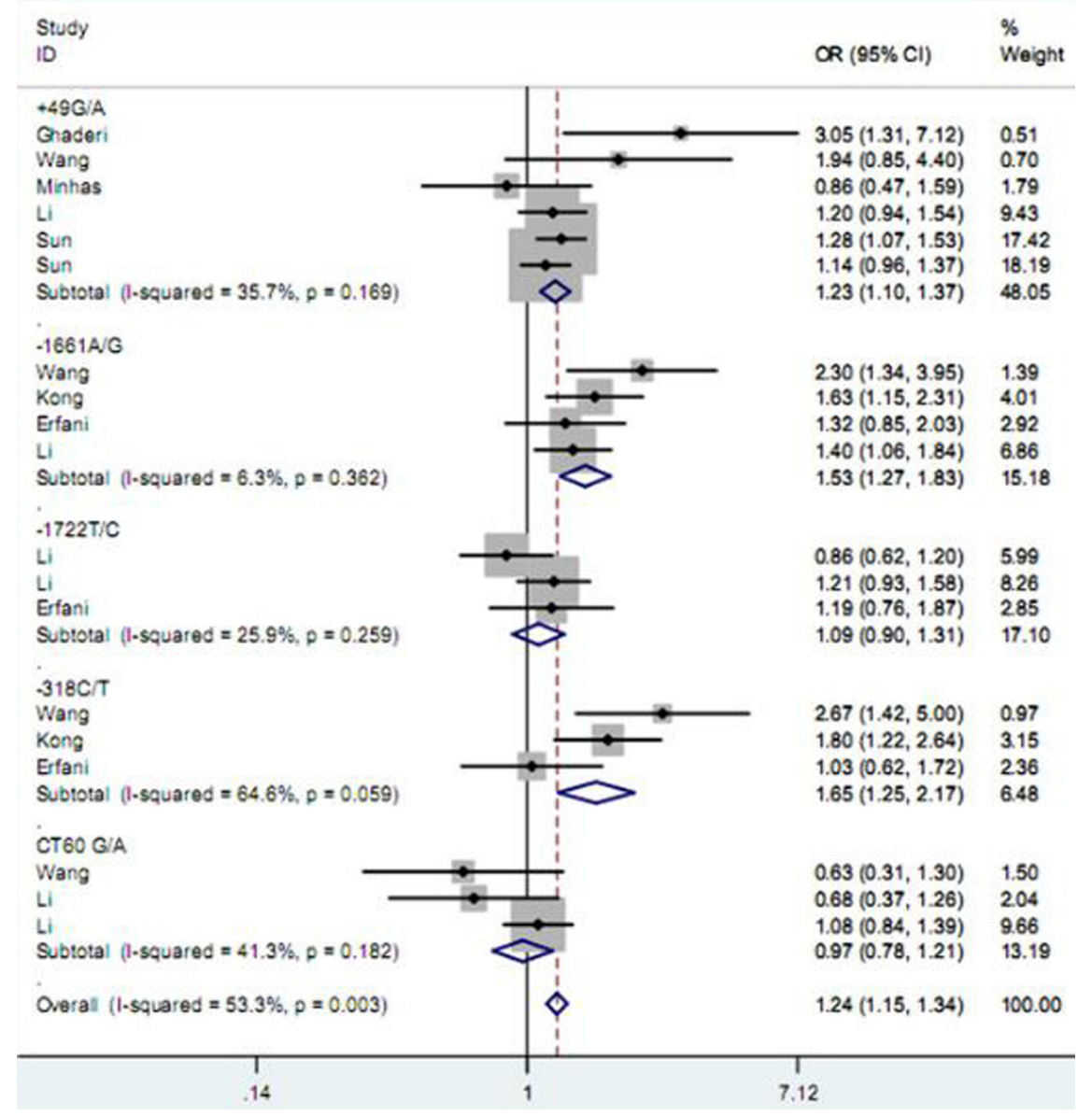

Figure 3: Forest plot for the association between CD152 polymorphisms and breast cancer susceptibility under heterozygote model.

Begg's funnel plot with pseudo $95 \%$ confidence limits

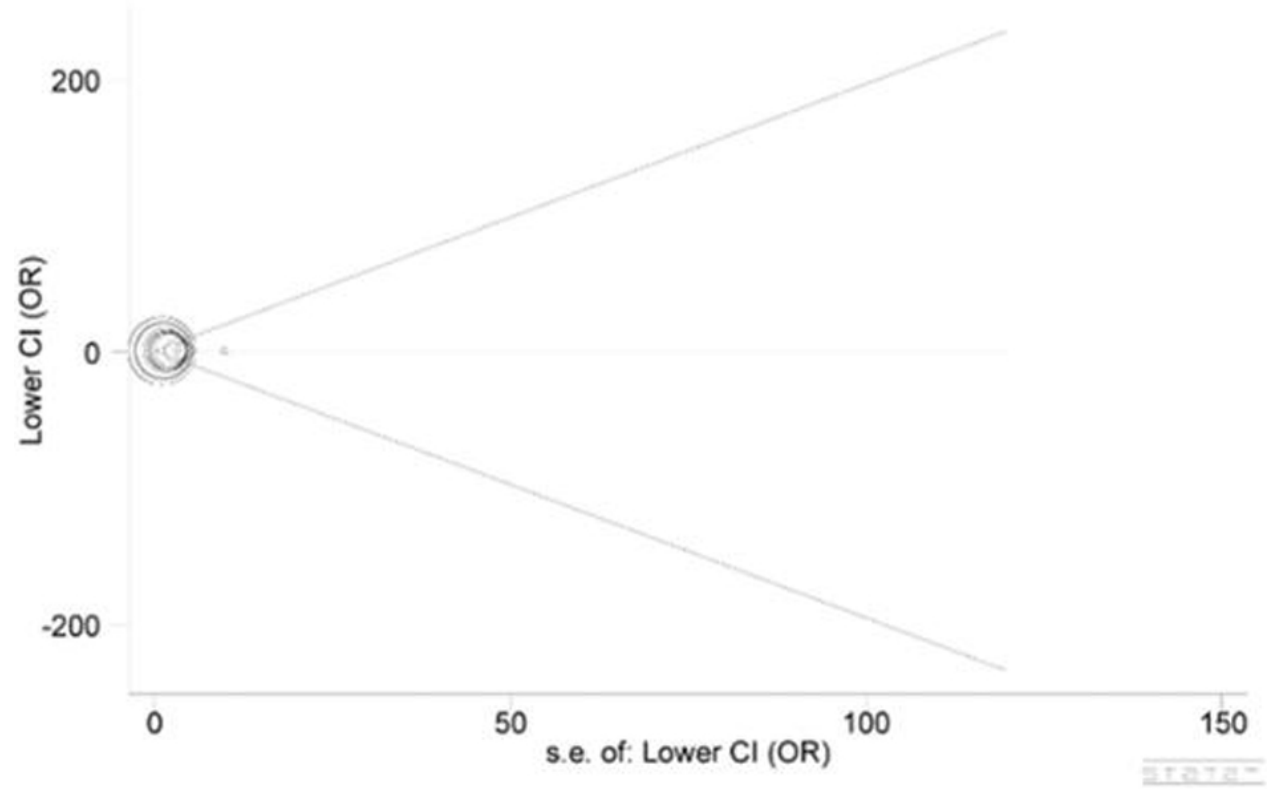

Figure 4: Begg's funnel plot for publication bias. 
gene consists of 4 exons and 3 introns, with more than 100 polymorphisms. These polymorphisms may alter the expression and/or the activity of the protein, thus being involved in the etiology of multiple diseases.

In the previous tumor investigations, a number of studies were carried out to estimate the association between the polymorphisms $(+49 \mathrm{G} / \mathrm{A},-1661 \mathrm{~A} / \mathrm{G}$, $-1722 \mathrm{~T} / \mathrm{C},-318 \mathrm{C} / \mathrm{T}$ and CT60 G/A) of CD152 gene and the susceptibility to $\mathrm{BC}$. Wang et al. found that the $-1661 \mathrm{~A} / \mathrm{G}$ polymorphism $\mathrm{G}$ allele, the $-318 \mathrm{C} / \mathrm{T}$ polymorphism $\mathrm{T}$ allele and the CT60 G/A polymorphism $\mathrm{G}$ allele were more frequent in $\mathrm{BC}$ patients than that in controls. They concluded that these alleles increased the risk of the cancer, while the $+49 \mathrm{G} / \mathrm{A}$ polymorphism was only associated with tumor size in the patients [25]. For $-1661 \mathrm{~A} / \mathrm{G}$ polymorphism, Li et al. got a similar result as Wang et al., but they insisted there was no significant correlation of $\mathrm{BC}$ with either the $+49 \mathrm{G} / \mathrm{A}$ or CT60 G/A polymorphism. Nevertheless, they put forward that the $\mathrm{CC}$ genotype and $\mathrm{C}$ allele of the -1722 $\mathrm{T} / \mathrm{C}$ polymorphism increased the risk of the cancer [26]. However, Erfani et al. revealed no significant difference of genotype or allele frequencies of $-1722 \mathrm{~T} / \mathrm{C},-1661$ $\mathrm{A} / \mathrm{G}$ and $-318 \mathrm{C} / \mathrm{T}$ polymorphisms between $\mathrm{BC}$ patients and healthy controls in Indians [27].

Based on Asian populations, these studies got no consistent opinion on the relationship between CD152 polymorphisms and $\mathrm{BC}$ susceptibility, which is the reason for us to perform this meta-analysis. Pooled analysis demonstrated that the $+49 \mathrm{G} / \mathrm{A},-1661 \mathrm{~A} / \mathrm{G}$ and -318 $\mathrm{C} / \mathrm{T}$ polymorphisms could increase the risk of $\mathrm{BC}$, while CT60 G/A polymorphism exerted an opposite function on the susceptibility to the malignancy. Meanwhile, -1722 T/C polymorphism did not show significant link with the cancer developing. The results were obtained based on strict analyses, but they still need to be identified by studies with larger sample sizes, due to some limitations in this meta-analysis. Firstly, the number of included studies was small, which might affect the comprehensiveness of the final outcomes. Secondly, subgroup analysis was not performed in the present study due to limited data. Thirdly, as we all know, BC was a complicated diseases caused by multiple factors and interactions among them, but this respect was not explored in our meta-analysis.

In summary, the $+49 \mathrm{G} / \mathrm{A},-1661 \mathrm{~A} / \mathrm{G}$ and -318 $\mathrm{C} / \mathrm{T}$ polymorphisms of the $C D 152$ gene have a positive relationship with $\mathrm{BC}$ susceptibility while the CT60 G/A polymorphism is negatively related to the cancer.

\section{MATERIALS AND METHODS}

\section{Literature searching strategy}

The electronic databases of PubMed, EMBASE, Google Scholar Web, CNKI and Wanfang were searched for studies on the association between $C D 152$ polymorphisms and $\mathrm{BC}$ risk, using the combination of key terms as followed: "Cluster of differentiation 152" or "CD152" or "cytotoxic T-lymphocyte-associated protein 4" or "CTLA4 " or "ALPS5" or "GSE", "breast cancer" or "breast carcinoma" or "mammary cancer", and "polymorphism" or "mutation" or "variant". Additionally, other sources and reference lists of relevant reports were also checked to supplement the results of database searching.

\section{Selection criteria}

The pre-designed criteria for each included study were as followed: with a case-control design; assessing the relationship between the CD152 polymorphisms and BC susceptibility; stating sufficient data on genotype and/ or allele frequencies of studied polymorphisms both in case and control groups for calculating odds ratios (ORs) with their corresponding 95\% confidence intervals (95\% CIs); and published in English or Chinese language. As for excluded publications, they met at least one of the following conditions: based on duplicated data; focusing on animals; and letters, commentaries, case report, review articles or conference abstracts. When the same group of study participants was incorporated into more than one report, the one with the largest sample size or most recently published was selected.

\section{Data extraction}

Two independent reviewers were in charge of extracting primary information from all eligible articles using the same data table. Essential information abstracted contained first author's name, publication year, original country, ethnicity, genotyping method, number of cases and controls, genotype and/or allele frequencies in case and control groups, and $P$ value for Hardy-Weinberg equilibrium (HWE) in controls. Any discrepancies over extracted data were settled through discussion between the two reviewers; if no consensus was reached through such approach, a third reviewer would be invited into the discussion.

\section{Statistical analysis}

The intensity of the association between $C D 152$ polymorphisms and $\mathrm{BC}$ susceptibility was appraised through calculating pooled ORs and their 95\% CIs. Heterogeneity between included studies was detected with $Q$ test. $P<0.05$ suggested significant heterogeneity, and the random-effects model was used; otherwise, the fixed-effects model was applied to assess the combined results. Sensitivity analysis was performed by omitting one study each time. Between-study publication bias was examined with both Begg's funnel plot and Egger's regression test. All these statistical analyses were completed with STATA 12.0 software (Stata Corporation, College Station, TX, USA). 


\section{CONFLICTS OF INTEREST}

None.

\section{REFERENCES}

1. Torre LA, Bray F, Siegel RL, Ferlay J, Lortet-Tieulent J, Jemal A. Global cancer statistics, 2012. CA Cancer J Clin. 2015; 65:87-108.

2. DeSantis C, Ma J, Bryan L, Jemal A. Breast cancer statistics, 2013. CA Cancer J Clin. 2014; 64:52-62.

3. Hery C, Ferlay J, Boniol M, Autier P. Changes in breast cancer incidence and mortality in middle-aged and elderly women in 28 countries with Caucasian majority populations. Annals of oncology. 2008; 19:1009-1018.

4. Jemal A, Bray F, Center MM, Ferlay J, Ward E, Forman D. Global cancer statistics. CA Cancer J Clin. 2011; 61:69-90.

5. Ban KA, Godellas CV. Epidemiology of breast cancer. Surgical oncology clinics of North America. 2014; 23: 409-422.

6. Chiranjeevi P, Spurthi KM, Rani NS, Kumar GR, Aiyengar TM, Saraswati M, Srilatha G, Kumar GK, Sinha S, Kumari CS, Reddy BN, Vishnupriya S, Rani HS. Gelatinase B $(-1562 \mathrm{C} / \mathrm{T})$ polymorphism in tumor progression and invasion of breast cancer. Tumour biology. 2014; 35:1351-1356.

7. Schwarzman MR, Ackerman JM, Dairkee SH, Fenton SE, Johnson D, Navarro KM, Osborne G, Rudel RA, Solomon GM, Zeise L, Janssen S. Screening for Chemical Contributions to Breast Cancer Risk: A Case Study for Chemical Safety Evaluation. Environmental health perspectives. 2015 .

8. Mavaddat N, Antoniou AC, Easton DF, Garcia-Closas M. Genetic susceptibility to breast cancer. Molecular oncology. 2010; 4:174-191.

9. Yu JC, Ding SL, Chang CH, Kuo SH, Chen ST, Hsu GC, Hsu HM, Hou MF, Jung LY, Cheng CW, Wu PE, Shen CY. Genetic susceptibility to the development and progression of breast cancer associated with polymorphism of cell cycle and ubiquitin ligase genes. Carcinogenesis. 2009; 30:1562-1570.

10. Maker AV, Phan GQ, Attia P, Yang JC, Sherry RM, Topalian SL, Kammula US, Royal RE, Haworth LR, Levy C, Kleiner D, Mavroukakis SA, Yellin M, et al. Tumor regression and autoimmunity in patients treated with cytotoxic $\mathrm{T}$ lymphocyte-associated antigen 4 blockade and interleukin 2: a phase I/II study. Annals of surgical oncology. 2005; 12:1005-1016.

11. Paterson AM, Vanguri VK, Sharpe AH. SnapShot: B7/CD28 costimulation. Cell. 2009; 137:974-974 e971.

12. Antczak A, Pastuszak-Lewandoska D, Gorski P, Domanska D, Migdalska-Sek M, Czarnecka K, Nawrot E, Kordiak J, Brzezianska E. Ctla-4 expression and polymorphisms in lung tissue of patients with diagnosed non-small-cell lung cancer. BioMed research international. 2013; 2013:576486.
13. Vetizou M, Pitt JM, Daillere R, Lepage P, Waldschmitt N, Flament C, Rusakiewicz S, Routy B, Roberti MP, Duong CP, Poirier-Colame V, Roux A, Becharef S, et al. Anticancer immunotherapy by CTLA-4 blockade relies on the gut microbiota. Science. 2015.

14. Higuchi T, Flies DB, Marjon NA, Mantia-Smaldone G, Ronner L, Gimotty PA, Adams SF. CTLA-4 Blockade Synergizes Therapeutically with PARP Inhibition in BRCA1-Deficient Ovarian Cancer. Cancer immunology research. 2015; 3:1257-1268.

15. Covre A, Coral S, Nicolay H, Parisi G, Fazio C, Colizzi F, Fratta E, Di Giacomo AM, Sigalotti L, Natali PG, Maio M. Antitumor activity of epigenetic immunomodulation combined with CTLA-4 blockade in syngeneic mouse models. Oncoimmunology. 2015; 4:e1019978.

16. Choi JM, Kim SH, Shin JH, Gibson T, Yoon BS, Lee DH, Lee SK, Bothwell AL, Lim JS. Transduction of the cytoplasmic domain of CTLA-4 inhibits TcR-specific activation signals and prevents collagen-induced arthritis. Proceedings of the National Academy of Sciences of the United States of America. 2008; 105:19875-19880.

17. Ruhi C, Sallakci N, Yegin O, Suleymanlar G, Ersoy FF. The influence of CTLA-4 single nucleotide polymorphisms on acute kidney allograft rejection in Turkish patients. Clinical transplantation. 2015; 29:612-618.

18. Banelli B, Morabito A, Laurent S, Piccioli P, Dozin B, Ghio M, Ascierto PA, Monteghirfo S, Marasco A, Ottaviano V, Queirolo P, Romani M, Pistillo MP. A novel multiplex pyrosequencing assay for genotyping functionally relevant CTLA-4 polymorphisms: potential applications in autoimmunity and cancer. Human immunology. 2014; 75:730-739.

19. Wang FY, Lu SG, Zhao T. CTLA-4 gene polymorphism and protein expression and apoptosis of peripheral blood lymphocytes from idiopathic nephrotic syndrome children with the pathologic type of mesangial proliferative glomerulonephritis [Article in Chinese]. Chinese journal of pediatrics. 2007; 45:633-634.

20. Eskandari-Nasab E, Moghadampour M, Najibi H, HadadiFishani M. Investigation of CTLA-4 and CD86 gene polymorphisms in Iranian patients with brucellosis infection. Microbiology and immunology. 2014; 58:135-141.

21. Liu J, Zhang HX. CTLA-4 polymorphisms and systemic lupus erythematosus: a comprehensive meta-analysis. Genetic testing and molecular biomarkers. 2013; 17:226-231.

22. Wang L, Jiang Z, Qiu H, Tang W, Duan T. Associations between CTLA-4 +49 A/G (rs231775) polymorphism and cancer risk: a meta-analysis based on 52 case-control studies. International journal of clinical and experimental medicine. 2015; 8:6835-6851.

23. Sun T, Zhou Y, Yang M, Hu Z, Tan W, Han X, Shi Y, Yao J, Guo Y, Yu D, Tian T, Zhou X, Shen H, et al. Functional genetic variations in cytotoxic T-lymphocyte antigen 4 and susceptibility to multiple types of cancer. Cancer research. 2008; 68:7025-7034. 
24. Ghaderi A, Yeganeh F, Kalantari T, Talei AR, Pezeshki AM, Doroudchi M, Dehaghani AS. Cytotoxic T lymphocyte antigen-4 gene in breast cancer. Breast cancer research and treatment. 2004; 86:1-7.

25. Wang L, Li D, Fu Z, Li H, Jiang W. Association of CTLA-4 gene polymorphisms with sporadic breast cancer in Chinese Han population. BMC cancer. 2007; 7:173.

26. Li D, Zhang Q, Xu F, Fu Z, Yuan W, Pang D. Association of CTLA-4 gene polymorphisms with sporadic breast cancer risk and clinical features in Han women of northeast China. Molecular and cellular biochemistry. 2012; 364(1-2):283-290.

27. Erfani N, Razmkhah M, Talei AR, Pezeshki AM, Doroudchi M, Monabati A, Ghaderi A. Cytotoxic T lymphocyte antigen-4 promoter variants in breast cancer. Cancer genetics and cytogenetics. 2006; 165:114-120.
28. Li H, Fu ZK, Wang LH, Li DL, Wu N, Zhang J, Li DJ. Association of cytotoxic $\mathrm{T}$ lymphocyte antigen-4 gene polymorphisms with susceptibility to breast cancer [Article in Chinese]. Chinese journal of cellular and molecular immunology. 2008; 24:282-284.

29. Minhas S, Bhalla S, Shokeen Y, Jauhri M, Saxena R, Verma IC, Aggarwal S. Lack of any association of the CTLA-4 +49 G/A polymorphism with breast cancer risk in a North Indian population. Asian Pacific journal of cancer prevention. 2014; 15:2035-2038.

30. Kong FJ. Association between polymorphisms of CTLA-4, IL-10 gene and breast cancer in Chinese Han population. The Fourth Military Medical University. 2010; 15:2039-2044. 